\title{
EVALUATION OF GENOTYPIC RESPONSE OF KABULI CHICKPEA (CICER ARIETINUM L.) CULTIVARS TO IRRIGATION REGIMES IN NORTHWEST OF IRAN
}

\author{
MOKHTAR PASANDI ${ }^{1}$, MOHSEN JANMOHAMMADI ${ }^{*}$, RAHMATOLLAH KARIMIZADEH $^{2}$
}

${ }^{1}$ University of Maragheh

${ }^{2}$ Dryland Agricultural Research Institute, Gachsaran

PASANDI, M. - JANMOHAMMADI, M. - KARIMIZADEH, R.: Evaluation of genotypic response of of Kabuli chickpea (Cicer arietinum L.) cultivars to irrigation regimes in Northwest of Iran. Agriculture (Pol'nohospodárstvo), vol. 60, 2014, no. 1, pp. $22-30$.

\begin{abstract}
Water deficiency is commonly the most important yield -restraining factor in semi-arid and Mediterranean environments. Chickpea (Cicer arietinum L.), which is one the main legume crops of the region, often experiences terminal drought. To investigate the response of chickpea genotypes to different irrigation levels, experiments were conducted in Maragheh, Northwest Iran. Three levels of irrigation including zero (rain-fed condition), full irrigation (enough water to fill the root zone profile) and two supplement irrigations (SIs) during flowering and grain filling stages were evaluated over 2013 growing season. Results revealed that plant height, canopy spread, primary and secondary branches, chlorophyll content, day to maturity, grain yield and yield components were significantly affected by irrigation regimes. However, there was no
\end{abstract}

statistically significant difference between full irrigation and SI for number of pods per plant, number of seeds per pod, 100-grain weight, grain yield per unit area and grain filling rate. The seed yield of the genotypes when grown under the full irrigation condition increased at a rate of $58 \%$ over those in rain-fed condition. Investigation of grain yield and drought resistance indices revealed that FLIP 98-106C and Arman can be selected as the best tolerant genotypes to rain-fed condition. In general, under semi-arid conditions and where some limited water resources are available, SI could be an efficient management practice for alleviating the unfavourable effects of soil moisture stress on the yield of rain-fed chickpea during crucial reproductive growth stages.

Key words: drought; genotype; grain yield; kabuli; rain-fed conditions

Chickpea (Cicer arietinum L.) is one of the earliest grain legumes believed to have originated in rainfed areas of the Mediterranean basin (Kumar \& Abbo 2001). Chickpea can be considered one of the most important food legumes in the world. Major chickpea producing countries include India, Pakistan and Iran (FAO 2008), where the crop is generally sown in spring (March-April) after the main rainy season, and when monthly rainfall decreases gradually till June. Chickpea is traditionally grown as a rain-fed crop on stored soil moisture and this makes terminal drought stress as a primary constraint to productivity
(Serraj et al. 2004). It covers $15 \%$ of the cultivated area and contributes to $14 \%$ (7.9 million ton) of the world's pulse harvest of about 58 million tons (FAO 2008). Besides being an important source of human and animal food, chickpea also plays an important role in the maintenance of soil fertility, particularly in the dry, rain-fed areas (Katerji et al. 2001; Gaur et al. 2007). Most chickpea growing areas in Iran have cool and cold semi-arid climates with terminal drought stress (Ghassemi-Golezani et al. 2008). In west and northwest of Iran with cold wet winters (December-February) and hot dry summers (June-

Eng. Mokhtar Pasandi, Dr. Mohsen Janmohammadi (*Corresponding author), Department of Agronomy and Plant Breeding, Agriculture College, University of Maragheh, P.O. Box 55181-83111, Iran. E-mail: jmohamad@alumni.ut.ac.ir Dr. Rahmatollah Karimizadeh, Dryland Agricultural Research Institute (DARI), Gachsaran, Iran 
August), chickpea is traditionally sown in spring (March-April), which roughly corresponds with the end of the rainy season in the region. Consequently, water deficit during late vegetative and reproductive stages is a common yield-limiting factor (Soltani et al. 2001). However, the severity of water stress varies from year to year, depending on the amount and distribution of rainfall and also the rate of evapotranspiration. Terminal drought stress is normally accompanied by increasing temperature during the time of maturity, often to levels more than $30^{\circ} \mathrm{C}$, which may affect pod filling (Khamssi et al. 2011). A scarcity of soil moisture in the rain-fed areas of Iran often arises during the most susceptible stages of chickpea growth, i.e. flowering and grain filling (Shamsi et al. 2010).

Irrigated agriculture is the primary user of diverted water globally, reaching a proportion that exceeds $70-80 \%$ of the total in the arid and semi-arid zones (Fereres \& Soriano 2007). However, rain-fed agriculture accounts for about $80 \%$ of the world's farmland and two-thirds of global food production. Despite the higher risks and generally lower productivity compared with irrigated areas, rain-fed agriculture will continue to play a dominant role in providing food and livelihood for an increasing world population (Oweis \& Hachum 2012). When water supplies are limited, the farmer's goal should be to maximise net income per unit water used (i.e. water productivity) rather than per land unit (Fan et al. 2005). Although chickpea is well adapted to semi-arid conditions and considering its winter cycle usually does not need irrigation, sometimes two or maximum three Supplemental Irrigations (SIs) are required. Supplemental irrigation could be introduced as an important strategy to increase water productivity in semi-arid regions. Supplemental irrigation may be defined as the providing of small quantities of water to rain-fed chickpea in order to promote and stabilise yield. SI is only applied when the rainfall fails to provide crucial moisture for normal plant growth especially during reproductive phase. Oweis and Hachum (2003) reported that application of SI in winter-sown food legumes in the Mediterranean environments could significantly improve grain yield and water productivity. Malhotra et al. (1997) found that supplemental irrigation $(80-120 \mathrm{~mm}$ ) could enhance the yields of winter-sown chickpea grown in the lowland Mediterranean drylands by $44.0 \%$. The ratio of increase based on estimated annual net profit per hectare to estimated difference in annual costs between rainfed systems and SI strategy is near to $200 \%$, which is considerable (Oweis \& Hachum 2006).

The present study was designed to determine the effect of different levels of water supply ranging from a zero to full irrigation on growth, yield and yield component of Kabuli chickpea genotypes. This study will provide information, which can be used in choosing suitable tolerant genotype and will be useful for farmers making decisions on irrigation in Mediterranean area.

\section{MATERIALS AND METHODS}

The present study was carried out on an Experimental Farm in Faculty of Agriculture at University of Maragheh in Northwest Iran during the 2013 spring season. Seven different Kabuli chickpea (Cicer arietinum L.) genotypes including five lines from the International Center for Agricultural Research in the Dry Areas (FLIP 03-71C, FLIP 03-64C, FLIP 98-106C, FLIP 00-40C and FLIP 9966C) and two checks from Iran (Arman and Azad) were grown as materials. The field was located at $46^{\circ} 16^{\prime}$ East longitude and $37^{\circ} 23^{\prime}$ 'North latitude, at an altitude of 1485 metres from sea level; based on Koppen's classification, this region has a semi-arid and cold temperate climate with an annual precipitation of $375 \mathrm{~mm}$, consisting of $73 \%$ rain and $27 \%$ snow. The soil type was a clay loam, $\mathrm{pH}$ of 6.85 and $\mathrm{EC}=0.84 \mathrm{ds} / \mathrm{m}$. Monthly meteorological data for the duration of the experiments are presented in Table 1 . The experimental fields were ploughed once in early fall and harrowed twice to bring the soil to fine tilth one week before planting. The recommended dose of fertiliser ( $30 \mathrm{~kg} \mathrm{~N}$ and $75 \mathrm{~kg} \mathrm{P}_{2} \mathrm{O}_{5} / \mathrm{ha}$ ) was applied in the form of urea and triple superphosphate at the time of seed bed preparation. The experimental design was factorial on the bases of randomised complete block in three replicates. Factors were seven chickpea cultivars and three irrigation regimes including zero irrigation (rain-fed condition that received natural rainfall only), full irrigation (receiving natural rainfall plus enough ir- 
rigation to fill the root zone profile) and two supplemental irrigations (SI) during flowering and grain filling stages. The amount of irrigation water was calculated to restore water content in the root zone to field capacity. Depth of net irrigation water fraction was $\sim 110 \mathrm{~mm}$. Seeds were hand-sown on 17 March 2013 in $4 \mathrm{~cm}$ depth of soil. Treatment plot size was $4 \times 3 \mathrm{~m}$ or $12 \mathrm{~m}^{2}$ (with a harvested area $4 \mathrm{~m}^{2}$ ). In each plot, seeds were sown into 16 rows, at $25 \mathrm{~cm}$ row-to-row spacing and $8 \mathrm{~cm}$ plant-to-plant spacing. Weeding was done manually. During the irrigations, plots were irrigated up to $70 \%$ of field capacity. All necessary cultural practices and plant protection measures were followed uniformly for all the plots during the entire period of experimentation. Planting days from sowing to $50 \%$ seedling emergence (DSE), days to initial flowering, days to maturity and reproductive period were determined as growth traits. Chlorophyll content was measured on ten leaves of five plants at each plot, using a portable chlorophyll meter (SPAD-502, Minolta, Japan) at full bloom stage (R2). Grain filling rate (GFR) was measured as methods described by Khamssi et al. (2011). At early flowering, 30 plants from the each genotype were marked. The day of tagging was referred to as 0 day and subsequent days as days after flowering (DAF). Then, five marked pods per plot were hand harvested five times at 6-day intervals and brought back to the laboratory. The pods were threshed and grains detached from the pods. Grains dry weight was determined after oven drying to constant weight at $75 \pm 1{ }^{\circ} \mathrm{C}$. A linear regression model (two parts) was used in order to estimate and analyse grain filling parameters:

$$
\mathrm{W}=\{\mathrm{a}+\mathrm{bt} \mathrm{t}<\mathrm{tm} ; \mathrm{a}+\mathrm{btm} \mathrm{t} \geq \mathrm{tm}\}
$$

where $\mathrm{W}$ is grain weight, $a$ the intercept, $b$ the GFR, $t$ the DAF and $t m$ the end of grain filling period (mass maturity time). At maturity, when seed moisture content was $16-18 \%$, the plants were cut off at ground level and dry weight of aboveground biomass was determined by oven drying for 5-7 days at $50^{\circ} \mathrm{C}$.

Data were recorded on random sample of 10 plants from each plot for plant height $[\mathrm{cm}]$, canopy spread $[\mathrm{cm}]$, length of pod bearing branch $[\mathrm{cm}]$, primary branches and secondary branches per plant, pods per plant, seeds per pod, 100 seed weight [g], biologi- cal yield $[\mathrm{kg} / \mathrm{ha}]$ and seed yield per plant $[\mathrm{kg} / \mathrm{ha}]$. Harvest Index was determined as the ratio of grain yield to biological yield. Some drought tolerance indices like as Stress Tolerance Index (STI; Fernández 1992), Stress Susceptibility Index (SSI; Fischer \& Maurer 1978), Mean Productivity (MP; Rosielle \& Hamblin 1981), Geometric Mean Productivity (GMP; Fernández 1992), Yield Stability Index (YSI; Bouslama \& Schapaugh 1984), Yield Index (YI; Lin et al. 1986) and Stress Tolerance (TOL; Rosielle \& Hamblin 1981) were used to identify high yielding and drought tolerant genotypes. The data were subjected to analysis of variance using MSTATC statistical package. Differences were compared by least significant difference test at alpha 0.05 .

\section{RESULTS AND DISCUSSION}

For DSE, there was a significant difference between both irrigation regimes and genotypes. Comparison of the DSE between irrigation regimes revealed that a small amount of irrigation $(30 \mathrm{~mm})$ immediately after sowing increased emergence rate up to $70 \%$. The highest rate of seedling emergence was recorded in lines FLIP 03-71C, FLIP 03-64C and FLIP 98-106C (Table 2). In rain-fed Mediterranean areas, a high rate of seedling emergence in spring crops, which leads to prompt plant establishment and early maturity to escape terminal heat and drought, tends to produce larger grain yields (Yau et al. 2011). In highland semi-arid zones, irrigation immediately after sowing can ensure early germination and greater use of spring rains improves crop yield (Tavakkoli \& Oweis 2004).

The effects of irrigation regimes and genotype on plants height were significant (Table 2). Full and supplemental irrigation (SI) caused the highest plant height and plant grown under rain-fed condition had the lowest height (Table 2). A similar trend was observed for canopy spread. The results are consistent with those of Shamsi et al. (2010) who found SI could significantly increase chickpea plant height. Comparison of plant height between genotypes showed that the highest height was related to cv. Azad and line FLIP 98-106C. There was no significant difference between Arman and lines FLIP 00-40C and FLIP 99-66C. The shortest height was 
observed in line FLIP 03-71C. Hawtin and Singh (1984) suggested that variation in plants height depends on variety, latitude and date of planting. The significant main effect of irrigation regimes and significant irrigation $\times$ genotype interaction were obtained for number of primary branches (Table 2). SI could considerably increase $(32 \%)$ the number of primary branches in comparison with rain-fed condition. The highest number of primary branches was recorded in FLIP 99-66C, Arman and FLIP
98-106C under full irrigated condition (Table 2). However, the effect of water supply during critical growth stages on number of secondary branches was more prominent than primary branches, so that SI increased the number of secondary about $128 \%$ over the rain-fed condition. The highest number of secondary branches was observed in FLIP 98-106C. This result is in agreement with the findings of Leport et al. (2006) who that showed in all early, mid and late stress treatments of secondary branches

$\mathrm{T}$ a

Weather data for the chickpea grown seasons in 2013 at Maragheh station

\begin{tabular}{|c|c|c|c|c|}
\hline Month & $\begin{array}{c}\text { Mean air temperature } \\
{\left[{ }^{\circ} \mathrm{C}\right]}\end{array}$ & $\begin{array}{c}\text { Total precipitation } \\
{[\mathrm{mm}]}\end{array}$ & $\begin{array}{c}\text { Relative humidity } \\
{[\%]}\end{array}$ & $\begin{array}{c}\text { Total evaporation } \\
{[\mathrm{mm}]}\end{array}$ \\
\hline March & 7.4 & 34.4 & 76 & 13 \\
April & 12.5 & 21.8 & 70 & 35 \\
May & 15.1 & 20.6 & 71 & 72 \\
Jun & 21.9 & 2.9 & 54 & 316 \\
July & 26.7 & 0 & 44 & 369 \\
\hline
\end{tabular}

T a b

Effect of irrigation regimes on some morphophysiological traits of chickpea genotypes

\begin{tabular}{|c|c|c|c|c|c|c|c|c|}
\hline Factor & DSE & $\mathrm{PH}$ & $\mathrm{CS}$ & NPB & NSB & CHL & DSF & DTM \\
\hline \multicolumn{9}{|c|}{ Irrigation (IR) } \\
\hline Zero & $24.72^{\mathrm{a}}$ & $24.28^{\mathrm{b}}$ & $13.81^{\mathrm{b}}$ & $2.93^{\mathrm{c}}$ & $6.51^{\mathrm{b}}$ & $40.24^{b}$ & $58.48^{\mathrm{b}}$ & $100.26^{c}$ \\
\hline Supplement Irrigation & $24.41^{\mathrm{a}}$ & $32.17^{\mathrm{a}}$ & $27.67^{\mathrm{a}}$ & $3.87^{\mathrm{b}}$ & $14.85^{\mathrm{a}}$ & $47.75^{\mathrm{ab}}$ & $63.13^{\mathrm{b}}$ & $124.05^{b}$ \\
\hline Full & $14.93^{\mathrm{b}}$ & $34.03^{\mathrm{a}}$ & $33.74^{\mathrm{a}}$ & $6.13^{\mathrm{a}}$ & $18.47^{\mathrm{a}}$ & $55.31^{\mathrm{a}}$ & $85.56^{\mathrm{a}}$ & $135.03^{\mathrm{a}}$ \\
\hline \multicolumn{9}{|c|}{ Genotype (G) } \\
\hline FLIP 03-71C & $24.52^{\mathrm{a}}$ & $24.63^{c}$ & $24.98^{\mathrm{a}}$ & $3.88^{\mathrm{a}}$ & $12.19^{\mathrm{ab}}$ & $48.31^{\mathrm{ab}}$ & $63.08^{\mathrm{d}}$ & $111.27^{\mathrm{c}}$ \\
\hline FLIP 03-64C & $22.41^{\mathrm{ab}}$ & $28.79^{\mathrm{bc}}$ & $24.19^{\mathrm{a}}$ & $3.96^{\mathrm{a}}$ & $10.66^{\mathrm{b}}$ & $46.22^{\mathrm{b}}$ & $65.51^{\mathrm{cd}}$ & $113.28^{c}$ \\
\hline FLIP 98-106C & $22.47^{\mathrm{ab}}$ & $34.65^{\mathrm{a}}$ & $27.16^{\mathrm{a}}$ & $5.21^{\mathrm{a}}$ & $17.28^{\mathrm{a}}$ & $50.48^{\mathrm{ab}}$ & $71.20^{\mathrm{bc}}$ & $118.66^{\mathrm{bc}}$ \\
\hline FLIP 00-40C & $20.40^{\mathrm{bc}}$ & $30.53^{\mathrm{ab}}$ & $23.47^{\mathrm{a}}$ & $3.31^{\mathrm{a}}$ & $10.32^{\mathrm{b}}$ & $47.24^{\mathrm{ab}}$ & $73.84^{\mathrm{b}}$ & $119.90^{\mathrm{abc}}$ \\
\hline FLIP 99-66C & $18.51^{\mathrm{c}}$ & $32.57^{\mathrm{ab}}$ & $25.25^{\mathrm{a}}$ & $4.74^{\mathrm{a}}$ & $12.84^{\mathrm{ab}}$ & $47.20^{\mathrm{ab}}$ & $69.32^{\mathrm{bcd}}$ & $117.10^{\mathrm{bc}}$ \\
\hline Arman & $19.97^{\mathrm{bc}}$ & $32.14^{\mathrm{ab}}$ & $26.01^{\mathrm{a}}$ & $4.68^{\mathrm{a}}$ & $13.41^{\mathrm{ab}}$ & $45.82^{\mathrm{b}}$ & $83.31^{\mathrm{a}}$ & $127.89^{\mathrm{ab}}$ \\
\hline Azad & $21.19^{\mathrm{b}}$ & $34.80^{\mathrm{a}}$ & $25.33^{\mathrm{a}}$ & $4.45^{\mathrm{a}}$ & $10.67^{\mathrm{b}}$ & $51.43^{\mathrm{a}}$ & $87.51^{\mathrm{a}}$ & $130.35^{\mathrm{a}}$ \\
\hline IR & ++ & ++ & ++ & ++ & ++ & ++ & ++ & ++ \\
\hline G & ++ & + & NS & NS & ++ & + & ++ & ++ \\
\hline $\mathrm{IR} \times \mathrm{G}$ & NS & NS & NS & + & NS & NS & NS & ++ \\
\hline
\end{tabular}

DSE - days from sowing to $50 \%$ seedling emergence, PH - plant height [cm], CS - canopy spread [cm], NPB - number of primary branches, NSB - number of secondary branches, CHL - chlorophyll content, DSF - days from sowing to flowering, DTM - days to maturity, IR - irrigation regimes and G - genotypes Mean values of the same category followed by different letters are significant at $P \leq 0.05$ level; ${ }^{++}$significant on 0.01 level; ${ }^{+}$significant on 0.05 level; ${ }^{\text {NS }}$ non-significant 
were more affected than primary ones. The indirect consequences of water deficit include its adverse effects on plant phenology, phasic development, growth, carbon assimilation, assimilate partitioning and plant reproduction processes. Phytohormones function to coordinate plant growth and development and play critical roles in developmental process. For instance, indole-3-acetic acid (auxin) and gibberellins have been shown to play essential roles in the regulation of internodes elongation (Yang et al. 1996). It seems that water stress may affect plant growth characteristics through changes in levels of plant hormones. Hamayun et al. (2010) reported that the level of endogenous growth hormones in soybean plant was affected by drought stress, as the contents of plant growth promoting hormone (gibberellin) declined, while those of jasmonic acid and abscisic acid increased under drought.

Effects of irrigation regimes and genotype were significant on chlorophyll content. Result showed that under rain-fed condition terminal drought stress imposed and resulted in significant decrease in chlo- rophyll content by $37 \%$ over to full irrigation (Table 2). At full bloom stage, variety Azad showed higher chlorophyll content than the other varieties. The interactions between genotype and irrigation regimes were not significant. The results are in agreement with Mafakheri et al. (2010) who described a significant decrease of chlorophyll content caused by water deficit in three Kabuli chickpea cultivars. A decrease of total chlorophyll with drought stress implies a lowered capacity for light harvesting. Since the production of reactive oxygen species is mainly driven by excess energy absorption in the photosynthetic apparatus, this might be avoided by degrading the absorbing pigments (Herbinger et al. 2002).

Results showed that the number of days from sowing to flowering (DSF) was significantly affected by irrigation regimes and cultivar (Table 2). The range in DSF was 49-74 under rain-fed condition and 72-90 under full irrigated. It was clear that moisture supply during the growing period had a strong influence on phenology, with high temperatures and the amount of water in the soil during

$\mathrm{T}$ a

Effect of irrigation regimes on yield, yield components and GFR of chickpea genotypes

\begin{tabular}{|c|c|c|c|c|c|c|c|}
\hline Irrigation & PN & $\mathrm{SN}$ & $100-\mathrm{GW}$ & GY & BY & $\mathrm{HI}$ & GFR \\
\hline \multicolumn{8}{|c|}{ Irrigation (IR) } \\
\hline Zero & $11.57^{\mathrm{b}}$ & $0.990^{\mathrm{b}}$ & $30.78^{b}$ & $922^{c}$ & $4,391^{\mathrm{b}}$ & $42.03^{b}$ & $9.61^{\mathrm{b}}$ \\
\hline Supplement Irrigation & $20.11^{\mathrm{a}}$ & $1.190^{\mathrm{b}}$ & $34.68^{\mathrm{a}}$ & $1,963^{\mathrm{ab}}$ & $7,697^{\mathrm{a}}$ & $45.25^{\mathrm{ab}}$ & $11.07^{\mathrm{a}}$ \\
\hline Full & $23.44^{\mathrm{a}}$ & $1.010^{\mathrm{ab}}$ & $34.22^{\mathrm{a}}$ & $2,221^{\mathrm{a}}$ & $10,144^{\mathrm{a}}$ & $46.95^{\mathrm{a}}$ & $11.19^{\mathrm{a}}$ \\
\hline \multicolumn{8}{|c|}{ Genotype (G) } \\
\hline FLIP 03-71C & $14.86^{\mathrm{c}}$ & $1.098^{\mathrm{ab}}$ & $34.15^{\mathrm{a}}$ & $1,384^{\mathrm{d}}$ & $5,660^{b}$ & $47.20^{\mathrm{a}}$ & $10.61^{\mathrm{ab}}$ \\
\hline FLIP 03-64C & $16.88^{\mathrm{bc}}$ & $1.053^{\mathrm{b}}$ & $35.88^{\mathrm{a}}$ & $1,635^{\mathrm{bc}}$ & $6,506^{\mathrm{b}}$ & $49.03^{\mathrm{a}}$ & $9.84^{b}$ \\
\hline FLIP 98-106C & $20.39^{\mathrm{a}}$ & $1.104^{\mathrm{ab}}$ & $33.27^{\mathrm{ab}}$ & $1,867^{\mathrm{a}}$ & $10,733^{\mathrm{a}}$ & $37.04^{\mathrm{c}}$ & $11.03^{\mathrm{a}}$ \\
\hline FLIP $00-40 \mathrm{C}$ & $16.67^{\mathrm{bc}}$ & $1.091^{\mathrm{ab}}$ & $34.70^{\mathrm{a}}$ & $1,585^{\mathrm{cd}}$ & $6,153^{b}$ & $50.51^{\mathrm{a}}$ & $9.92^{\mathrm{b}}$ \\
\hline FLIP 99-66C & $21.05^{\mathrm{a}}$ & $1.097^{\mathrm{ab}}$ & $29.16^{c}$ & $1,727^{\mathrm{abc}}$ & $8,135^{\mathrm{ab}}$ & $42.96^{\mathrm{ab}}$ & $10.68^{\mathrm{ab}}$ \\
\hline Arman & $20.61^{\mathrm{a}}$ & $1.132^{\mathrm{a}}$ & $31.05^{\mathrm{bc}}$ & $1,881^{\mathrm{a}}$ & $9,027^{\mathrm{ab}}$ & $43.09^{\mathrm{ab}}$ & $10.98^{\mathrm{a}}$ \\
\hline Azad & $18.35^{\mathrm{b}}$ & $1.100^{\mathrm{ab}}$ & $35.42^{\mathrm{a}}$ & $1,817^{\mathrm{ab}}$ & $8,695^{\mathrm{ab}}$ & $43.32^{\mathrm{ab}}$ & $11.37^{\mathrm{a}}$ \\
\hline IR & ++ & ++ & ++ & ++ & ++ & ++ & ++ \\
\hline G & + & + & ++ & ++ & ++ & ++ & + \\
\hline $\mathrm{IR} \times \mathrm{G}$ & NS & + & Ns & NS & NS & + & NS \\
\hline
\end{tabular}

PN - pod number, SN - seed number, 100-GW - 100-grain weight [g], GY - grain yield [kg/ha], BY - biological yield [kg/ha], HI - harvest index [\%], GFR - grain filling rate [mg/day], IR - irrigation regimes and G - genotypes Mean values of the same category followed by different letters are significant at $P \leq 0.05$ level 
$\mathrm{T}$ a

Mean comparison of drought tolerance indices among chickpea genotypes

\begin{tabular}{|l|c|c|c|c|c|c|c|}
\hline Genotype & SSI & MP & TOL & STI & GMP & YI & YSI \\
\hline FLIP 03-71C & $0.833^{\mathrm{c}}$ & $1,419.17^{\mathrm{b}}$ & $952.64^{\mathrm{c}}$ & $0.391^{\mathrm{b}}$ & $1,331.00^{\mathrm{ab}}$ & $1.022^{\mathrm{ab}}$ & $0.513^{\mathrm{a}}$ \\
FLIP 03-64C & $1.135^{\mathrm{ab}}$ & $1,605.07^{\mathrm{ab}}$ & $1,595.35^{\mathrm{ab}}$ & $0.398^{\mathrm{b}}$ & $1,392.40^{\mathrm{ab}}$ & $0.875^{\mathrm{bc}}$ & $0.337^{\mathrm{bc}}$ \\
FLIP 98-106C & $0.894^{\mathrm{bc}}$ & $1,795.28^{\mathrm{a}}$ & $1,314.39^{\mathrm{abc}}$ & $0.561^{\mathrm{a}}$ & $1,662.28^{\mathrm{a}}$ & $1.233^{\mathrm{a}}$ & $0.472^{\mathrm{ab}}$ \\
FLIP 00-40C & $0.891^{\mathrm{bc}}$ & $1,395.90^{\mathrm{b}}$ & $1,063.00^{\mathrm{bc}}$ & $0.342^{\mathrm{b}}$ & $1,278.14^{\mathrm{b}}$ & $0.936^{\mathrm{b}}$ & $0.479^{\mathrm{ab}}$ \\
FLIP 99-66C & $1.010^{\mathrm{abc}}$ & $1,470.44^{\mathrm{ab}}$ & $1,257.60^{\mathrm{abc}}$ & $0.360^{\mathrm{b}}$ & $1,325.96^{\mathrm{ab}}$ & $0.912^{\mathrm{b}}$ & $0.412^{\mathrm{abc}}$ \\
Arman & $1.151^{\mathrm{a}}$ & $1,705.04^{\mathrm{ab}}$ & $1,716.00^{\mathrm{a}}$ & $0.452^{\mathrm{ab}}$ & $1,472.32^{\mathrm{ab}}$ & $0.918^{\mathrm{b}}$ & $0.320^{\mathrm{c}}$ \\
Azad & $0.904^{\mathrm{abc}}$ & $1,613.54^{\mathrm{ab}}$ & $1,190.00^{\mathrm{abc}}$ & $0.469^{\mathrm{ab}}$ & $1,498.19^{\mathrm{ab}}$ & $1.104^{\mathrm{b}}$ & $0.472^{\mathrm{abc}}$ \\
\hline
\end{tabular}

SSI- stress susceptibility index, MP- mean productivity, TOL - stress tolerance, STI - stress tolerance index, GMP- geometric mean productivity, YI- yield index, YSI- yield stability index

Mean values of the same category followed by different letters are significant at $P \leq 0.05$ level

the last months of spring time to flowering greatly reduced. Similarly, time to maturity was extended by high moisture supply and reduced by drought. Irrigation extended reproductive growth. Lines from ICARDA flowered first, followed by Iranian check cultivars (Arman and Azad).

The yield response of chickpea genotypes to irrigation regimes is given in Table 3. The effects of irrigation and genotype on number of pods, seed number per pod, 100-grain weight, grain yield, biological yield and harvest index were significant, while interaction of irrigation $\times$ genotypes was only significant for seed number per pod and harvest index. All yield components significantly decreased by terminal drought stress (rain-fed condition). SI could increase the number of pods per plant by $73 \%$ over the rain-fed condition. However, there was no difference between full irrigation and SI conditions. A similar status was observed for 100-grain weight, grain yield and biological yield. Although Arman and FLIP 98-106C had the highest number of pod and number of seeds per pod, these had the lowest 100-grain weight (Table 3). The highest number of seeds per pod was obtained by full irrigation. Water application at flowering and pod filling stage increased the number of seeds per pod by $21 \%$ over rain-fed condition. Biological yield of FLIP 98-106C and Arman was significantly higher than those of the other cultivars. However, the lowest harvest index was recorded for FLIP 98-106C. The supplementary irrigation positively influenced grain yield in all seven genotypes and showed an increase from 76 to $153 \%$. These results confirm those obtained in Mediterranean environments (Shamsi et al. 2010; Oweis \& Hachum 2012).

Investigation of the GFR showed that SI could increase GFR by $15 \%$, compared with the plants grown under the rain-fed condition. The highest GFR was recorded in FLIP 98-106C, Arman and Azad. The rate of grain filling is linear for a relatively long period of time from around pod forming to near physiological maturity. Providing good management during the period can help to provide a high GFR and, in some cases, may extend the grain filling period a few days thereby increasing yields. Availability of water for crop growth is the largest single controllable factor during this period. Sadeghipour (2008) reported that environmental stresses such as water shortages, especially during grain filling, cause reductions in photosynthesis and remobilisation of stored materials, rate and duration of grain filling and grain weight. Water stress generally accelerates leaf senescence and shortens grain filling duration as shown for chickpea (Chowdhury et al. 2002).

Previous field studies have shown that in a Mediterranean-type environment, water deficits develop near the onset of podding (Turner 2003), induce faster and shorter seed filling (Mafakheri et al. 2010), reduce pod and seed number, and reduce seed yield and seed size (Leport et al. 2006; Khamssi et al. 2011). The performance of spring-sown chickpea 
depends on the amount of moisture stored in the soil profile and the capacity of the root system to extract it. The cultivars with deep root systems can extract water at the greatest depths both under drought and irrigated conditions (Turner 2003; Oweis \& Hachum 2012).

Stress intensity calculation based on equation $(S I)=1-($ yield under rain-fed condition/yield under full irrigated environment) suggested that plants grown under rain-fed condition experienced a drought stress intensity with 0.58 . Mean comparisons of drought resistance indices are shown in Table 4. On the basis of seed yield under rainfed condition ( $\mathrm{Y}_{\mathrm{s}}$ ), line FLIP 98-106C gave a higher yield than the best check; Arman and FLIP 9966C showed the lowest. However, Arman and FLIP 98-106C gave the highest yields and FLIP 03-71C the lowest in full irrigated environment $\left(\mathrm{Y}_{\mathrm{p}}\right)$. The highest mean productivity (MP), mean productivity (MP), STI and GMP were recorded for line FLIP 98-106C. The highest value of tolerance index (TOL) and STI was observed for cv. Arman, which resulted from high $Y_{p}$. Conversely, the lowest values were recorded in line FLIP 03-71C. However, line FLIP 03-71C showed the highest value of YSI and the lowest value was related to Arman. YSI evaluates the yield under stress of a genotype relative to its non-stress yield, and should be an indicator for drought tolerant genetic materials. Therefore, the genotypes with high YSI are expected to have few yield losses under stress environments. The highest value of YI was observed for line FLIP 98-106C. YI ranks genotypes only on basis of their yield under stress. In general, FLIP 98-106C and Arman could be introduced as suitable genotypes for semi-arid conditions.

\section{CONCLUSIONS}

Nowadays, irrigation is the largest single consumer on the planet. In semi-arid areas, competition for water from other sectors will force irrigation to operate under the condition of water scarcity. Chickpea production under rain-fed conditions is low and subject to substantial year-to-year fluctuation due to erratic rainfall and its poor distribution. In the region, it seems that chickpea grain yield and water productivity can be greatly increased by supplemental irrigation, which is applied at flowering and/ or grain filling stage to reduce the water shortage stress. The major traits of adaptation for spring season legumes in low rainfall Mediterranean-type environments are early flowering and seed set before the onset of terminal drought. In addition, limited supplemental irrigation in the most susceptible periods will secure yield. The present study revealed that yield of chickpea could be substantially enhanced and stabilised with minimal irrigation, together with higher yield potential. The most impressive implication from this study is the saving in irrigation water with little loss in yield. However, where irrigation water is available, early germination and emergence can be ensured by applying a small irrigation immediately after sowing. Among the investigated genotypes, FLIP 98-106C and Arman showed the best performance under SI conditions.

\section{REFERENCES}

BOUSLAMA, M. - SCHAPAUGH, W.T. 1984. Stress tolerance in soybean. Part. 1: Evaluation of three screening techniques for heat and drought tolerance. In Crop Sciences, vol. 24, pp. 933-937. DOI:10.2135/ cropsci1984.0011183X002400050026x.

CHOWDHURY, M.A. - VANDENBERG, V. - WARKENTIN, T. 2002. Cultivar identification and genetic relationship among selected breeding lines and cultivars in chickpea (Cicer arietinum L.). In Euphytica, vol. 127, pp. 317-325. DOI: 10.1023/A:1020366819075.

FAN, T. - STEWART, B.A. - PAYNE, W.A. - WANG, Y. - SONG S. - LUO, J. - ROBINSON, C.A. 2005. Supplemental irrigation and water: yield relationships for plasticulture crops in the loess plateau of China. In Agronomy Journal, vol. 97, pp. 177-188. DOI: 10.2134/agronj2005.0177.

FAO. 2008. FAOSTAT, Food and Agriculture Organization of the United Nations Rome, Italy. Available at: http://faostat.fao.org.

FERERES, E. - SORIANO, M.A. 2007. Deficit irrigation for reducing agricultural water use. In Journal of Experimental Botany, vol. 58, pp. 147-159. DOI: $10.1093 / \mathrm{j} x \mathrm{~b} / \mathrm{er} 1165$.

FERNÁNDEZ, G.C. 1992. Effective selection criteria for assessing plant stress tolerance. In Proceedings of the International Symposium on "Adaptation of Vegetables and other Food Crops in Temperature and Water Stress", Chapter 25, Taiwan, 13-16 August, pp. 257-270.

FISCHER, R.A. - MAURER, R. 1978. Drought resistance in spring wheat cultivars. 1. Grain yield response. In Australian Journal of Agricultural Research, 
vol. 29, pp. 897-912. DOI:10.1071/AR9780897.

GAUR, P.M. - GOWDA, C.L. - KNIGHTS, E.J. 2007. Breeding achievement. In YADAV, S.S. - REDDEN, R. - CHEN, W. - SHARMA, B. (eds). Chickpea breeding and management. Cromwell Press, Trowbridge, UK : CABI, pp. 391-416.

GHASSEMI-GOLEZANI, K. - DALIL, B. - MUHAMMADI-NASAB, A.D. - ZEHTAB S. 2008. The Response of Chickpea Cultivars to Field Water Deficit. In Notulae Botanicae Horti AgrobotaniciCluj-Napoca, vol. 36, pp. 25-28.

HAMAYUN, M. - AFZAL-KHAN, S. - SHINWARI, Z.K. - KHAN A.L. - AHMAD N. - LEE, I.J. 2010. Effect of polyethylene glycol induced drought stress on physio-hormonal attributes of soybean. In $\mathrm{Pa}$ kistan Journal of Botany, vol. 42, pp. 977-986. DOI 10.1007/s00344-012-9274-8.

HAWTIN, G.C. - SINGH, K.B. 1984. Prospects and potential of Winter sowing of chickpea in the Mediterranean Region. In SAXENA, M.C. - SINGH, K.B. - MARTINUS N. - Junk, W. (eds.) Ascochyta blight and Winter sowing of chickpea. The Hague, The Netherlands : Junk Publishers, pp. 7-16.

HERBINGER, K. - TAUSZ, M. - WONISCH, A. - SOJA G. - SORGER, A. - GRILL, D. 2002. Complex interactive effects of drought and ozone stress on the antioxidant defence systems of two wheat cultivars. In Plant Physiology and Biochemistry, vol. 40, pp. 691-696. DOI:10.3109/07388550903524243.

KATERJI, N. - VAN HOORN, J.W. - HAMDY, A. MASTRORILli, M. - OWIES, T. - MALHOTRA, R.S. 2001. Response to soil salinity of chickpea varieties differing in drought tolerance. In Agricultural Water Management, vol. 50, pp. 83-96. http://dx.doi. org/10.1016/S0378-3774(01)00107-X.

KHAMSSI, N.N. - GHASEMI-GOLEZANI, K. - NAJAPHY, A. - ZEHTAB, S. 2011. Evaluation of grain filling rate, effective grain filling period and resistance indices under acclimation to gradual water deficit stress in chickpea cultivars. In Australian Journal of Crop Sciences, vol. 5, pp. 1044-1049. http://eprints. icrisat.ac.in/id/eprint/3740.

KUMAR, J. - ABBO, S. 2001. Genetics of flowering time in chickpea and its bearing on productivity in semiarid environments. In Advances in Agronomy, vol. 72, pp.107-138. http://dx.doi.org/10.1016/S00652113(01)72012-3.

LEPORT, L. - TURNER, N.C. - DAVIES, S.L. SIDDIQUE, K.H. 2006. Variation in pod production and abortion among chickpea cultivars under terminal drought. In The European Journal of Agronomy, vol. 24, pp. 236-246. http://dx.doi.org/10.1016/j. eja.2005.08.005.

LIN, C.S. - BINNS, M.R. - LEFKOVITCH, L.P. 1986. Stability analysis: where do we stand? In Crop Sciences, vol. 26, pp. 894-900. DOI:10.2135/cropsci1986.0011183X002600050012x.

MAFAKHERI, A. - SIOSEMARDEH, A. - BAHRAMNEJAD, B. - STRUIK, P.C. - SOHRABI, Y. 2010. Effect of drought stress on yield, proline and chlorophyll contents in three chickpea cultivars. In Australian
Journal of Crop Science, vol. 4, pp. 580-585. http:// www.cropj.com/mafakheri-4-8-2010-580-585.

MALHOTRA, R.S. - SINGH, K.B. - SAXENA, M.C. 1997. Effect of irrigation on winter-sown chickpea in a mediterranean environment. In Journal of Agronomy and Crop Science, vol. 178, pp. 237-243. DOI: 10.1111/j.1439-037X.1997.tb00496.x.

OWEIS, T. - HACHUM, A. 2003. Improving water productivity in the dry areas of West Asia and North Africa. In KIJNE, W.J. - BARKER, R. - MOLDEN, D. - (eds.) Water productivity in agriculture: limits and opportunities for improvement. Wallingford, UK : CABI Publishing, pp. 179-198.

OWEIS, T. - HACHUM, A. 2006. Water management in rainfed agriculture - investing in supplemental irrigation. In Shaping the future of water for agriculture : Agricultural water sourcebook. Washington, DC, USA : World Bank, pp. 206-213.

OWEIS, T. - HACHUM, A. 2012. Supplemental irrigation, a highly efficient water-use practice. Aleppo, Syria : ICARDA, pp. 2-28.

ROSIELlE, A.A. - HAMBLIN, J. 1981. Theoretical aspects of selection for yield in stress and non-stress environments. In Crop Sciences, vol. 21, pp. 943-946. DOI: $10.2135 /$ cropsci1981.0011183X002100060033x.

SADEGHIPOUR, O. 2008. Effect of withholding irrigation at different growth stages on yield and yield components of mungbean (Vicia radiata L.) varieties. In American-Eurasian Journal of Agricultural \& Environmental Sciences, vol. 4, pp. 590-594.

SERRAJ, R. - KRISHNAMURTHY, L. - KASHIWAGI, J. - KUMAR J. - CHANDRA, S. - CROUCH, J.H. 2004. Variation in root traits of chickpea (Cicer arietinum) grown under terminal drought. In Field Crops Research, vol. 88, pp. 115-127. http://dx.doi. org/10.1016/j.fcr.2003.12.001.

SHAMSI, K. - KOBRAEE, S. - HAGHPARAST, R. 2010. Drought stress mitigation using supplemental irrigation in rainfed chickpea (Cicer arietinum L.) varieties in Kermanshah, Iran. In African Journal of Biotechnology, vol. 9, pp. 4197-4203. DOI: 10.5897/ AJB09.1843.

SILIM, S.N. - SAXENA, M.C. 1993. Adaptation of spring-sown chickpea to the Mediterranean basin. I. Response to moisture supply. In Field Crops Research, vol. 34, pp. 121-136. http://dx.doi.org/10.1016/03784290(93)90001-4.

SOLTANI, A. - KHOOIE, F.R. - GHASSEMI-GOLEZANI, K. - MOGHADAM, M. 2001. A simulation study of chickpea crop response to limited irrigation in a semiarid environment. In Agricultural Water Management, vol. 49, pp. 225-237. http://dx.doi.org/10.1016/ S0378-3774(00)00143-8.

TALEBI, R. - BAGHEBANI, N. - KARAMI, E. - ENSAFI, M.H. 2011. Defining selection indices for drought tolerance in chickpea under terminal drought stresses. In Journal of Applied Biological Sciences, vol. 5, pp. 33-38.

TAVAKKOLI, A.R. - OWEIS, T. 2004. The role of supplemental irrigation and nitrogen in producing bread wheat in the highlands of Iran. In Agricultural Water 
Management, vol. 65, pp. 225-236. DOI:10.1016/j. agwat.2003.09.001.

TURNER, N.C. 2003. Adaptation to drought: lessons from studies with chickpea. In Indian Journal of Plant Physiology, Special Issue, pp. 11-17. http://repository.uwa.edu.au:80/R/-?func.

YANG, T. - DAVIES, P.J. - REID, J.B. 1996. Genetic dissection of the relative roles of Auxin and Gibberellin in the regulation of stem elongation in in- tact light-grown peas. In Plant Physiolgy, vol. 110, pp.1029-1034. DOI: 10.1104/pp.110.3.1029.

YAU, S.K. - NIMAH, M. - FARRAN, M. 2011. Early sowing and irrigation to increase barley yields and water use efficiency in Mediterranean conditions. In Agricultural Water Management, vol. 98, pp. 1776-1781. http://dx.doi.org/10.1016/j.agwat.2011.07.009.

Received: October 22, 2013 